\section{Association between stress and breast cancer in women: a meta-analysis}

\author{
Associação entre estresse e câncer \\ de mama feminino: metanálise
}

\author{
1 Faculdade de Farmácia, \\ Odontologia e Enfermagem, \\ Universidade Federal do \\ Ceará, Fortaleza, Brasil. \\ 2 Programa de Pós-graduação \\ em Epidemiologia, \\ Universidade Federal de \\ Pelotas, Pelotas, Brasil. \\ 3 Faculdade de Medicina, \\ Universidade Federal do \\ Ceará, Fortaleza, Brasil. \\ ${ }^{4}$ Hospital Universitário \\ Walter Cantídio, \\ Universidade Federal do \\ Ceará, Fortaleza, Brasil. \\ 5 Escola de Enfermagem de \\ Ribeirão Preto, Universidade \\ de São Paulo, Ribeirão Preto, \\ Brasil. \\ Correspondence \\ A. F. C. Fernandes \\ Faculdade de Farmácia \\ Odontologia e Enfermagem, \\ Universidade Federal do \\ Ceará. \\ Rua Lauro Maia 950, apto. 402, \\ Fortaleza, CE \\ 60005-210, Brasil. \\ afcana@ufc.br
}

\begin{abstract}
The objective of the current meta-analysis was to verify the association between stressful life events and primary breast cancer incidence in women. A total of 618 studies from 19822007 were found in the PubMed, LILACS, and Cochrane Library databases. Methodological quality was evaluated according to the Downs \& Black criteria. Eight studies were selected (six case-controls and two cohorts). The studies were grouped in three analyses, two of which based on the categories widowhood and divorce and the other based on self-rated intensity and frequency of stressful events. Relative risks were: widowhood 1.04 (95\%CI: 0.75-1.44; $p=0.800$ ); divorce 1.03 (95\%: 0.72-1.48; $p=$ 0.850); and intensity/frequency of stress 1.73 (95\%CI: 0.98-3.05; $p=0.059$ ). We conclude that stressful life events as a whole are not associated with risk of breast cancer in women. However, it is not possible to rule out high-intensity stress as a risk factor for breast cancer.
\end{abstract}

Life Change Events; Psychological Stress; Breast Neoplasms
Míria Conceição Lavinas Santos 1

Bernardo Lessa Horta 2

João Joaquim Freitas do Amaral 3

Paula Frassinetti Castelo Branco

Camurça Fernandes 4

Cristina Maria Galvão 5

Ana Fátima Carvalho Fernandes 1

\section{Introduction}

Breast cancer in women is one of the main public health problems worldwide, due to its magnitude (high morbidity and mortality) and transcendence (high social and economic cost). It has thus been the subject of extensive international discussion on risk evaluation 1,2 .

Various risk factors for breast cancer have been established in both the Brazilian and international literature 3,4 . Among these factors, age is definitely the most important, followed by family history. Researchers agree that such factors have been the main focus for both the prevention and early diagnosis of breast cancer 4,5,6.

However, cancer in women has a multifactorial etiology and can originate from a combination of genetic, environmental, and lifestyle factors that make women susceptible to breast cancer 4,7 .

Secondary factors like stress could have a less pronounced association, and would thus not necessarily be identified as risk factors in primary studies. A positive association between stress and breast cancer was observed in cohort studies 8,9 and some case-control studies 9,10,11,12,13,14,15, while other case-control studies do not indicate evidence of such an association 16,17.

A growing number of studies 18,19,20,21,22,23 have been conducted to investigate this possible causality, specifically linked to stressful life events: divorce, death of husband or child, 
friend's illness, personal health problems, change in marital status (separation, divorce, or widowhood), change in financial status, or death of close relatives.

Two recent studies show conflicting results concerning the target event. A prospective cohort study concluded that stressful life events in women are associated with increased incidence of breast cancer 8 . There is a biological plausibility to this correlation, since high estrogen concentration is characterized as a risk factor for breast cancer, that is, inhibition of estrogen synthesis induced by chronic stress could explain the increased incidence of breast cancer in women exposed to high degrees of stress. Meanwhile, a case-control study indicated no correlation between stress and breast cancer incidence 20 .

Thus, this possible association has not been based on sufficient clinical and epidemiological evidence, thereby leading to conflicting results. The findings from the above-mentioned studies motivated us to conduct the current systematic review, with the aim of searching the literature for evidence of an association between stressful life events and primary breast cancer incidence in women.

\section{Methods}

A systematic review and meta-analysis were conducted with primary cohort and case-control studies, with the following basic question: are women exposed to stressful life events at increased risk of developing breast cancer?

\section{Search strategy}

A systematic review was according to the Cochrane Handbook model produced by the Cochrane Collaboration 24. We searched the MEDLINE (PubMed), LILACS (Latin American and Caribbean Health Sciences Literature), and Cochrane Library electronic databases to identify studies published from 1982 to July 2007.

The database search strategy used the Medical Subject Headings (MesSH) terms and proximity operators $(* ; "$;) with the following combinations of terms and key words: life events, adverse life events, breast cancer, female, stress, stressful, change events, case-control studies, cohort study.

\section{Inclusion and exclusion criteria}

The following inclusion criteria were adopted for the studies: (a) type of study - prospective and historical cohort study and case-control study; (b) type of sample - women 18 years or older with first occurrence of breast cancer in cohort studies and in case-control studies with the appearance of the first breast cancer; (c) mean follow-up time - minimum of ten years in cohort studies, while in case-control studies no limit was set on the period between exposure and diagnosis; (d) type of variable - studies in which the stress variable was measured quantitatively; stress measured with a numerical scale, questionnaire, and checklist; stress measured against frequency of exposure and intensity of the event; (e) statistical type and analysis - studies that calculated relative risk (RR) for the first episode of breast cancer in relation to the stress variable, adjusting for the following confounding factors (age, use of oral contraceptives, any type of hormone replacement, menopause, alcohol intake, smoking, socioeconomic status, and family history of breast cancer).

The exclusion criteria for studies were: (a) articles on work-related or environmental stress or daily activities, post-traumatic stress; lifestyle and daily stress; (b) studies focusing on the association between breast cancer and personality type and anxiety; social, psychological, and psychosocial support; (c) stress in women with a psychiatric history; (d) breast cancer recurrence and other diseases of the breast; (e) surgical and clinical intervention (radiotherapy and chemotherapy); and (f) literature review articles and editorials.

\section{Strategy for article identification and selection and data collection}

First, the article titles and abstracts were evaluated by three reviewers, verifying each primary study that addressed the systematic review's underlying question. The abstracts were grouped into selected versus not selected.

The selected articles were retrieved, read in full, and screened for those indexed in more than one source or in another language.

In the next phase, data from the selected studies were assigned to an instrument to verify whether they met the inclusion and exclusion criteria, and discrepancies were resolved by discussion and consensus. Studies for which there was no agreement as to inclusion were analyzed by a fourth reviewer.

Data from the case-control and cohort studies were assigned to a structured form containing: author's name, year of publication, study's country of origin, type of study, adjustment for confounding factors, and odds ratios (OR) and respective $95 \%$ confidence intervals $(95 \% \mathrm{CI})$. The data were reviewed by the four reviewers. 


\section{Methodological quality}

Methodological quality was evaluated using the scale proposed by Downs \& Black 25. The instrument was a checklist consisting of 27 items distributed in five subscales: (1) communication (9 items) - whether the information provided by the article was sufficient to allow the reader to detect biases in the study's results; (2) external validity ( 3 items) - in which the study's results can be generalized to the population from which the subjects came; (3) internal validity - bias (7 items) - whether there is bias in measuring the intervention and the result; (4) internal validity - confounding factors/selection bias (6 items) - whether there is bias in subject selection; (5) power (1 item) - whether negative findings can be related to chance; and (6) validation of the study's power (1 item). Each study was scored from 0 to 1 on each answer, with the exception of the first item, communication, scored from 0 to 2 , and the last item, study power, scored from 0 to 5 . The instrument's maximum total score is 31 .

We thus analyzed the cohort studies based on 19 items $(1,2,3,5,6,7,9,10,11,12,16,17,18$, $20,21,22,25,26,27)$ and the case-control studies based on 17 items $(1,2,3,5,6,7,10,11,12$, $16,17,18,20,21,22,25,27)$. Items 9 and 26 were not used in the evaluation of case-control studies since they contain questions that do not apply to this type of study. Items 4, 8, 13, 14, 15, 19, 23, and 24 were not scored because they pertain to intervention studies, since no publication included in this review was of the experimental type.

Other items that were evaluated included: whether the study provided estimates of the random variability in the main findings; whether losses to follow-up were described; whether the probability values for the main outcomes were specified; whether the sample of subjects invited to participate in the study was representative; whether the sample of subjects included in the study was representative; if the results were not based on a priori hypotheses, whether this was made clear; in trials and cohort studies, whether the analysis was adjusted for different follow-up times, or in case-control studies, whether the intervention and outcome time was the same for cases and controls; whether the statistical tests used to measure the principal outcomes were appropriate; whether the measurements of the principal outcomes were accurate (valid and reliable); whether the patients in different groups were recruited from the same population; whether the patients in different groups were recruited during the same time period; whether the analysis included adequate adjustment for the main confounding factors; whether losses to follow-up were considered; and whether the study had sufficient power to detect an important effect with $5 \%$ significance.

\section{Statistical analysis}

Statistical analysis used the Stata program, version 9.0 (Stata Corp., College Station, USA).

To allow a meta-analysis of the eight selected studies, they were grouped into three distinct analyses. Two analyses referred to the three studies that calculated relative risk for breast cancer as a function of stressful life events: the categories widowhood and separation (divorce) 9,26,27.

Six studies calculated relative risk for breast cancer without considering categories, but rather self-rated intensity or frequency of stressful events, regardless of the situation that caused it $8,9,14,15,16,17$. We chose the RR related to the highest intensity in each article, ignoring the RR related to stressful events rated as less intense or less frequent.

Four studies classified intensity as rated by the subjects themselves 8,14,15,16.

Ginsberg et al. 15, using a system based on Tennant/Andrews, classified participants in four groups based on score: 0-70, 71-140, 141-210, $>210$. We considered the result for participants scoring greater than 210 .

Chen et al. 14 classified their sample in five groups: women who felt little or no threat from the events and those that felt slightly, moderately, or heavily threatened. We considered the result for women that felt heavily threatened.

Helgesson et al. 8 classified the stressful event dichotomously, as whether or not it had produced intense stress (yes or no). We considered the result for women that answered yes.

Protheroe et al. 16 used a 4-point scale of selfrated stress, with 1 to 2 points representing mild stress and 3 to 4 points reflecting severe stress. We only considered severe stress.

Two studies 9,17 investigated intensity using the number (frequency) of events, based on the logic that more events would be related to more stress (intensity): Lillberg et al. ${ }^{9}$ used the modified Holmes-Rahe questionnaire, including the possibility of checking 21 stressful items, and classified the group in four: no event, one event, two events, and three or more (we considered the result for three or more events) and Robert et al. 17, including the possibility of 11 events and comparing the observed frequencies between cases and controls (we considered the mean score between the two groups of patients). Thus, the total number of studies is greater than eight, because one study calculated RR for both the category and the intensity of stress 9 . 
We used the Q test to evaluate the heterogeneity among studies and the random effects model to calculate the combined effect, i.e., the RR of the meta-analysis. Due to the small number of studies, we did not conduct sensitivity or bias analyses. The studies' level of evidence was classified as proposed by Melnyk \& FineoutOverholt 28.

\section{Results}

The search strategy identified 619 titles and abstracts. Of these articles, 554 were excluded after reading the titles and abstracts. We selected 65 abstracts whose full texts were obtained for analysis and application of the inclusion and exclusion criteria, and 57 articles were excluded for the following reasons:

Two studies 10,20 did not present the RR and $95 \% \mathrm{CI}$ for the association between stressful life events and breast cancer. These missing data were requested from the authors by e-mail, but the latter did not reply.

Seventeen studies 29,30,31,32,33,34,35,36,37,38,39,40, $41,42,43,44,45$ described risk factors related to psychiatric, psychological, or social disorders; six referred to other types of stress (stress and work 46,47 ; stress and daily activities 48,49; post-traumatic stress 50; stress and lifestyle 51). Fourteen 12, $21,22,23,52,53,54,55,56,57,58,59,60,61$ evaluated the psychosocial approach, and there were six editorials $62,63,64,65,66,67$ and three literature reviews $68,69,70$.

We also excluded an update study 71 on the relationship between stress and breast cancer; five studies on personality and breast cancer $72,73,74,75,76$; and three meta-analyses, on the relationship between stressful events and breast cancer 18; the association between breast cancer and life events in general 19 ; and psychosocial factors and breast cancer 77 .

As for level of evidence, the eight studies were classified as level IV, referring to evidence from well-designed cohort and case-control studies 28 .

The majority of the studies showed satisfactory methodological quality according to the Downs \& Black classification 25. The cutoff point for characterizing the studies as having a high methodological score was the median value of the studies, or 17 (Table 1). According to the Downs \& Black criteria 25 , the maximum possible total score was 20 points for cohort studies and 18 points for case-control studies. Due to the limited variation in scores, the eight studies were considered representative and were included in the systematic review and selected for the metaanalysis.
Among the eight studies included in the meta-analysis, six were case-controls 14,15,16,17,26,27 and two were cohort studies 8,9. The eight studies included a total of 66,612 women.

The two cohort studies included in the meta-analysis were from Sweden 8 and Finland 9 . Their combined population consisted of 12,270 women. The mean age for the sample in the first study was 47.2 years, and the second was limited to women older than 24 years. The types of stress measured in the two studies were stressful events and divorce and widowhood, respectively. The six case-control studies 14,15,16,17,26,27 were from Denmark, England, Norway, Australia, and the United States. The combined population consisted of 54,342 women. The types of stress measured were: life events, stressful life events, and divorce and widowhood (Table 1).

The Q test showed heterogeneity in the three analyses for the risk factors widowhood $(\mathrm{Q}=$ 7.634; $\mathrm{p}=0.020)$, divorce $(\mathrm{Q}=9.591 ; \mathrm{p}=0.008)$, and stress intensity $(\mathrm{Q}=24.688 ; \mathrm{p}<0.001)$. We used the random effects model to calculate the combined effect, i.e., the RR of meta-analysis.

The first analysis considered studies on the association between widowhood and breast cancer 9,26,27 (Figure 1). These three studies were used in the second analysis with divorce as the risk factor (Figure 2). The third analysis included studies with self-rated intensity of stress as the risk factor, considering the RR for the highest intensity in the studies 8,9,14,15,16,17 (Figure 3).

Among the three studies included in the meta-analysis on widowhood as risk factor, none was conclusive 9,26,27. The meta-analysis showed a lack of association between widowhood and breast cancer risk, with $\mathrm{RR}=1.04$ (95\%CI: 0.75 1.44; $\mathrm{p}=0.800$ ), as shown in Figure 1.

Among the three studies included in the meta-analysis on divorce as risk factor 9,26,27, the study by Lillberg ${ }^{9}$ concluded that divorce is a risk factor for breast cancer $(\mathrm{RR}=2.07$; $95 \% \mathrm{CI}$ : 1.16 3.67). However, our meta-analysis showed no association between divorce and breast cancer, with $\mathrm{RR}=1.03$ (95\%CI: $0.72-1.48 ; \mathrm{p}=0.850)$, as shown in Figure 2.

Among the six studies 8,9,14,15,16,17 on the association between high-intensity stress and breast cancer, two 8,14 conclusively showed such an association: Chen et al. 14 , with $\mathrm{RR}=7.08(95 \% \mathrm{CI}$ : 2.31-21.6), and Helgesson et al. 8, with $\mathrm{RR}=2.1$ (95\%CI: 1.2-3.7). However, the other four were inconclusive 9,15,16,17. According to our metaanalysis, there was only a borderline risk of breast cancer due to intense stress: $\mathrm{RR}=1.73$ (95\%CI: 0.98-3.05; $\mathrm{p}=0.059$ ), as shown in Figure 3. 
Table 1

Characteristics of studies included in the meta-analysis and score on Downs \& Black scale 25.

\begin{tabular}{|c|c|c|c|c|c|c|c|}
\hline Authors & Country/Year & Design & Sample size & Age (mean) & Type of stress & $\begin{array}{c}\text { Result } \\
\text { RR ** }(95 \% \mathrm{Cl})\end{array}$ & $\begin{array}{c}\text { Downs \& } \\
\text { Black score } 25\end{array}$ \\
\hline Ewertz 27 & Denmark/1986 & Case-control & $1,782 / 1,738$ & $<70$ * & $\begin{array}{c}\text { Divorce } \\
\text { Widowhood }\end{array}$ & $\begin{array}{l}0.9(0.7-1.2) \\
0.8(0.7-1.0)\end{array}$ & 14 \\
\hline Kvikstad et al. 26 & Norway/1994 & Case-control & $4,491 / 44,910$ & $40-60$ * & $\begin{array}{c}\text { Divorce } \\
\text { Widowhood }\end{array}$ & $\begin{array}{c}0.83(0.75- \\
0.92) \\
1.13(0.94- \\
1.36)\end{array}$ & 17 \\
\hline Chen et al. 14 & England/1995 & Case-control & $41 / 78$ & $57.0 / 50.0$ & Life events & $\begin{array}{c}7.08(2.31- \\
21.65)\end{array}$ & 18 \\
\hline Ginsberg et al. 15 & Australia/1996 & Case-control & $99 / 99$ & - & $\begin{array}{l}\text { Stressful life } \\
\text { events }\end{array}$ & $\begin{array}{c}2.24(0.92- \\
5.44)\end{array}$ & 17 \\
\hline Roberts et al. 17 & $\begin{array}{c}\text { United } \\
\text { States/1996 }\end{array}$ & Case-control & $158 / 614$ & $64.8 / 62.4$ & $\begin{array}{l}\text { Stressful life } \\
\text { events }\end{array}$ & $0.9(0.78-1.05)$ & 18 \\
\hline Protheroe et al. 16 & Australia/1999 & Case-control & $106 / 226$ & $61.6 / 51.8$ & $\begin{array}{l}\text { Stressful life } \\
\text { events }\end{array}$ & $\begin{array}{c}0.91(0.47- \\
1.73)\end{array}$ & 17 \\
\hline Helgesson et al. 8 & Sweden/2003 & Cohort & 1,462 & 47.2 & $\begin{array}{l}\text { Stressful } \\
\text { events }\end{array}$ & $2.1(1.2-3.7)$ & 20 \\
\hline Lillberg et al. 9 & Finland/2003 & Cohort & 10,808 & $>24$ * & $\begin{array}{c}\text { Divorce } \\
\text { Widowhood }\end{array}$ & $\begin{array}{c}2.07(1.16- \\
3.67) \\
1.64(0.84- \\
3.19)\end{array}$ & 20 \\
\hline
\end{tabular}

95\% Cl: 95\% confidence interval; RR: relative risk.

* Age limit;

Figure 1

Relative risks and combined effect on breast cancer due to widowhood.

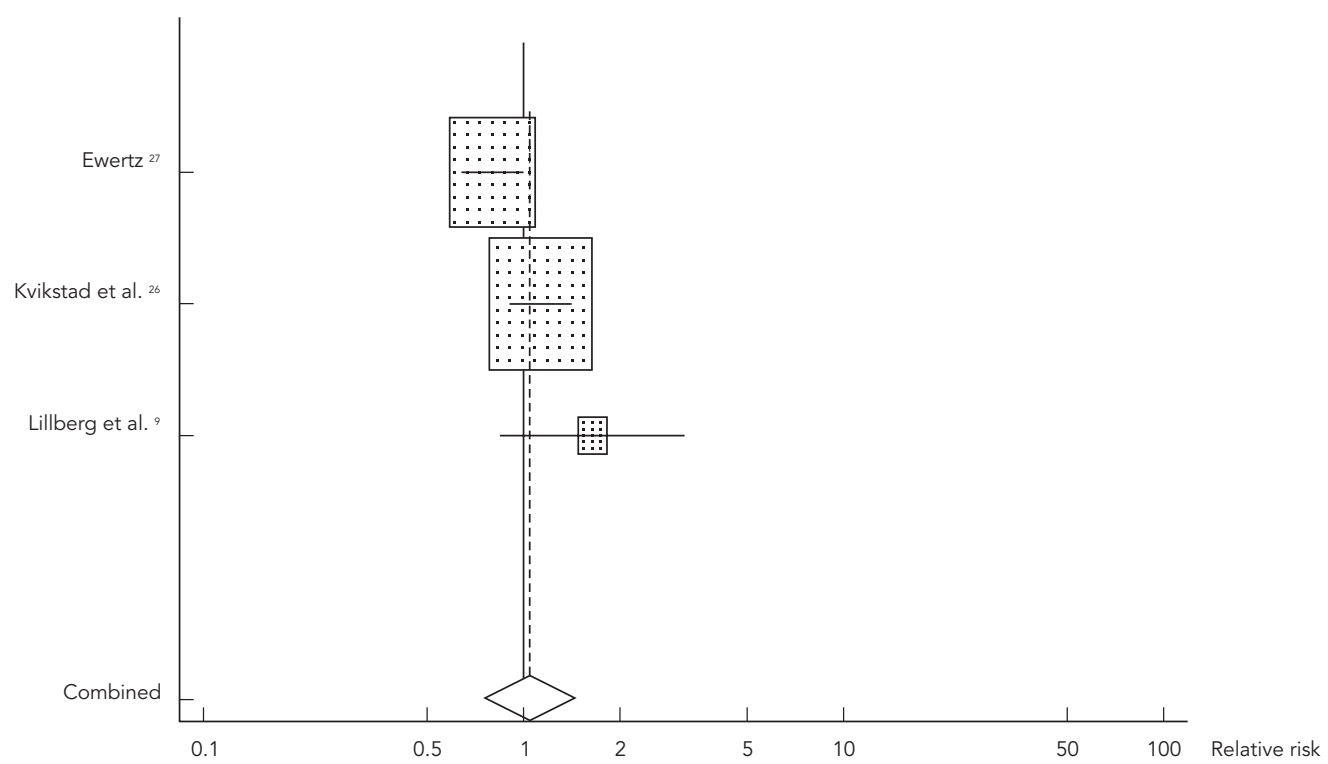


Figure 2

Relative risks and combined effect on breast cancer due to divorce.

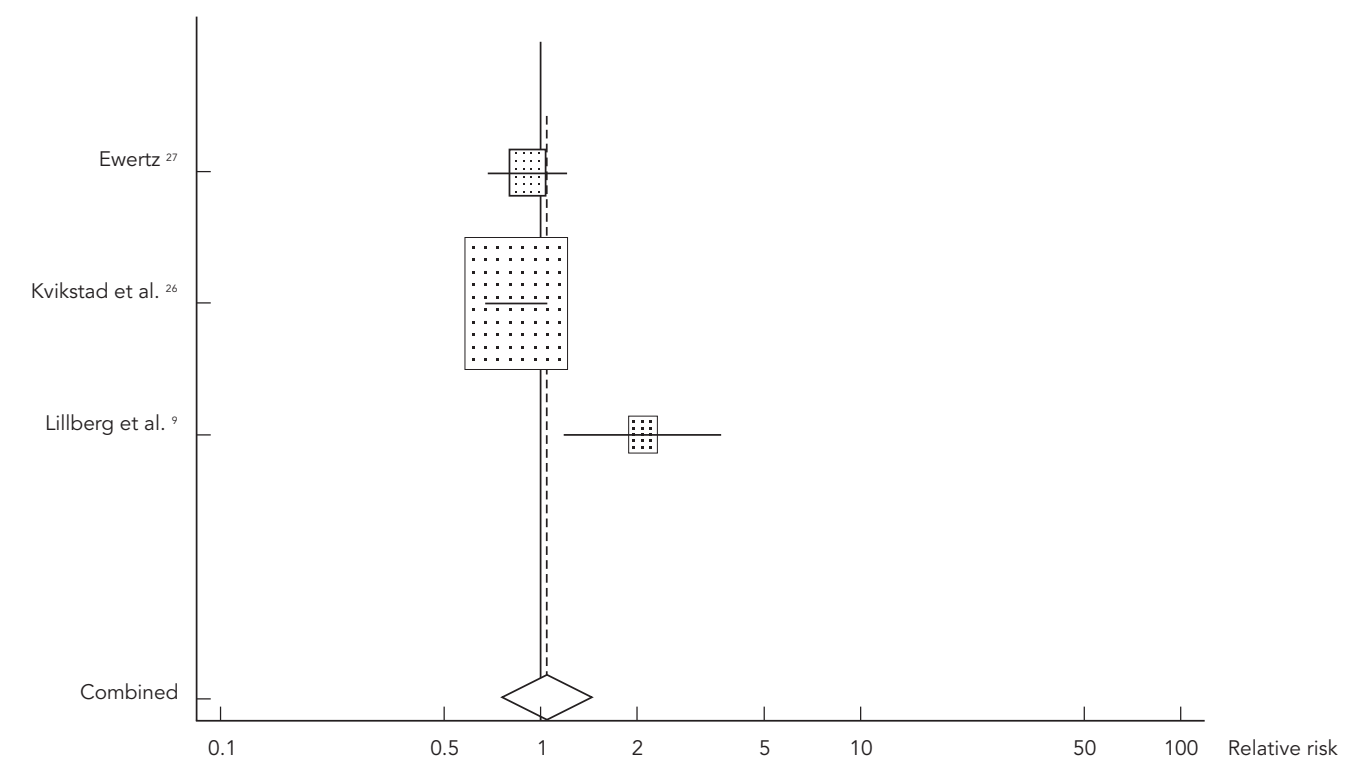

Figure 3

Relative risks and combined effect on breast cancer due to high-intensity stress.

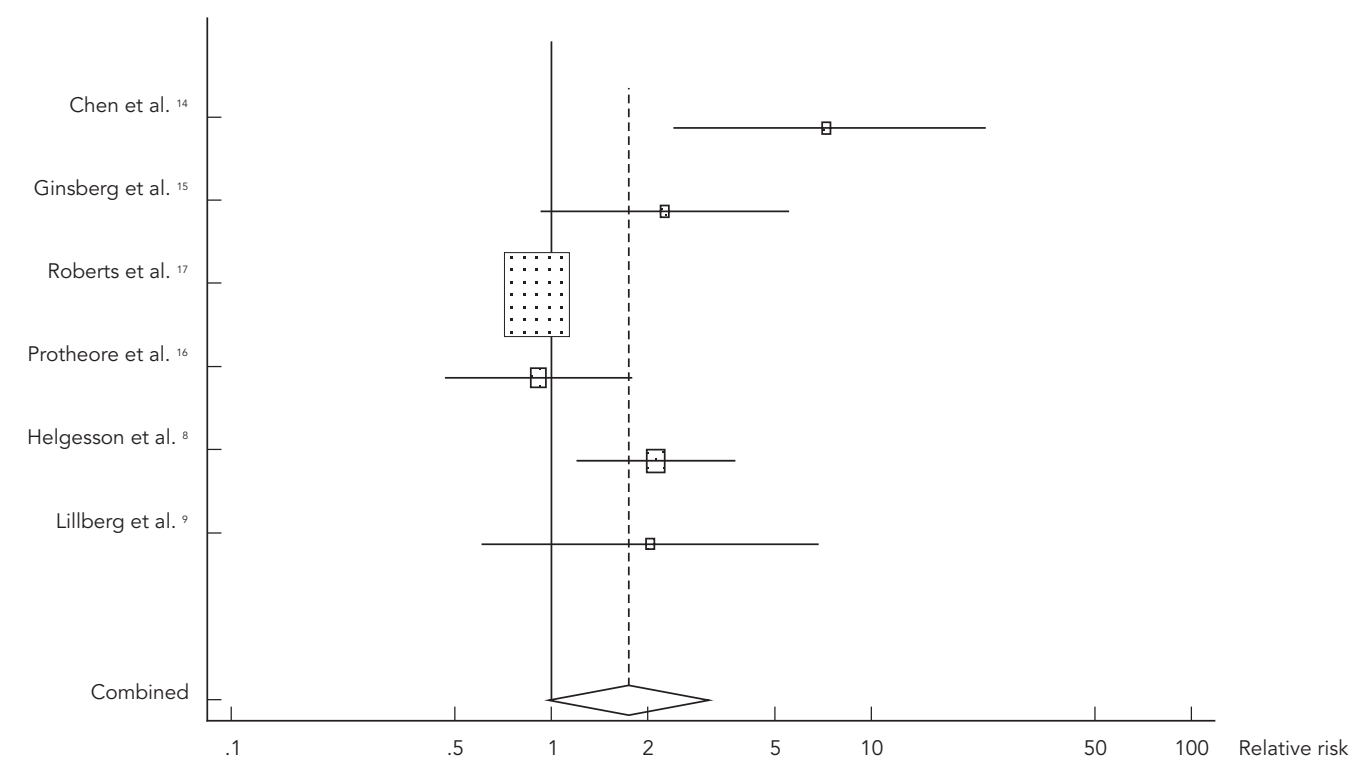




\section{Discussion}

The results of the current meta-analysis do not show evidence of an association between stressful life events and primary breast cancer incidence in women. Similar findings were reported in two meta-analyses on the association between stressful events and breast cancer in women 18,19.

The first meta-analysis, with 29 studies, showed lack of support for a causal relationship between negative life events and breast cancer incidence $\left(\mathrm{OR}=0.8 ;\right.$ 95\%CI: 0.96-1.06) ${ }^{18}$. According to the second, with 27 studies, which evaluated the categories death of husband, death of friend, health problems, financial problems, and change in marital status, there was no association between stressful events and breast cancer $(\mathrm{OR}=$ 1.77; 95\%CI: 1.37-2.40), but there was a slight association between husband's death and risk of breast cancer $(\mathrm{OR}=1.37$; 95\%CI: 1.10-1.71) 19 .

Considering the methodological quality of the reviewed articles, the eight studies were methodologically homogeneous, with a mean score of 17 points out of a maximum of 20 points, according to the Downs \& Black criteria 25 . These criteria have been used in meta-analyses 78,79 and systematic reviews 80,81 and provide an adequate instrument for use in systematic reviews like ours 82 .

In the majority of the studies the event was investigated adequately, combining subjectivity and objectivity, with the application of instruments (scale, questionnaires, and checklist), thus reducing the possibility of recall bias 83,84 . They also considered the type of stressful agent by categories, intensity, and frequency of exposure, thus allowing the evaluation of the appropriate events from the point of view of the literature 84,85 .

Although the studies were classified as evidence IV according to the classification system used in this meta-analysis 28 , it would not be possible to answer the question on stress and risk of breast cancer according to levels of evidence II and III, namely evidence derived from clinical trials. Observational studies are considered appropriate for conducting systematic reviews, according to members of the non-randomized studies in the Cochrane Collaboration, and are also the most adequate for determining risk factors 86,87 , while emphasizing the importance of careful assessment of the studies' design.

As for the population, our findings refer to a total sample of 66,612 women participating in the eight studies. This ensures great statistical power. However, despite the significant sample size, we should point to some limitations in the current study. First, two studies identified in the initial systematic review 10,20 were excluded due to lack of data presented by the authors, and if used they might have been representative in the review, although they did not find an association between stress and breast cancer. Second, the inclusion of a larger number of studies might have allowed analyzing the studies for sensitivity and possible biases.

As for the electronic article search, we intentionally excluded articles that evaluated women with breast cancer relapse, since these women could present emotional responses that could lead to an increase in the target events, relating them to the risk of falling ill. We would thus prevent the findings from this meta-analysis from being conclusive as to the risk of stress leading to breast cancer, due to the woman's optimistic bias concerning her risk of developing this type of cancer.

When we analyzed the effect of high-intensity stressors, the meta-analysis suggests that an association may exist, and a statistically significant effect was observed in the studies with the largest sample size. This same result was not identified in other epidemiological studies and suggests that future research should further consider the evaluation of factors associated with breast cancer incidence in women.

This literature review identified a lack of Brazilian studies on the association between stress and breast cancer. Thus, the main sources of information were international studies, conducted mainly in countries with Nordic women, with a distinct cultural profile from that of Brazilian women. Future analyses are necessary to verify whether these findings will be corroborated in difference ethnic populations.

\section{Conclusion}

Research on stress and breast cancer has been documented by various studies published over the years. Data from the current study corroborate findings already published in the literature on the lack of evidence for an association between stressful life events (divorce and widowhood) and risk of breast cancer in women. However, our results point to high-intensity stress as having a borderline association with the development of breast cancer. Future studies are necessary to elucidate this relationship. 


\section{Resumo}

O objetivo da presente metanálise foi verificar a associação de eventos de vida produtores de estresse com a incidência primária do câncer de mama entre as mulheres. Foram encontrados 618 estudos nas bases PubMed, LILACS e Biblioteca Cochrane Library, no período de 1982-2007. A qualidade metodológica foi avaliada pelos critérios de Downs \& Black. Foram selecionados oito estudos, sendo seis caso-controle e dois de coorte. Os estudos foram agrupados em três análises, duas em virtude das categorias viuvez e divórcio, e uma considerando a intensidade autopercebida e freqüência de eventos. O risco relativo em relação à viuvez foi 1,04 (IC95\%: 0,75-1,44; $p=0,800$ ); ao divórcio foi 1,03 (IC95\%: 0,72-1,48; $p=0,850$ ), e em relação ao grau intensidade/freqüencia de estresse foi 1,73 (IC95\%: 0,98-3,05; $p=0,059$ ). Concluímos que os eventos de vida produtores de estresse não têm associação de risco com câncer de mama feminino. O estresse de alta intensidade não permite eliminar a possibilidade de associação de risco para o câncer de mama.

Acontecimentos que Mudam a Vida; Estresse Psicológico; Neoplasias da Mama

\section{Contributors}

A. F. C. Fernandes oriented the study, participated in drafting the article, and approved the final version for publication. M. C. L. Santos contributed to the research project's conceptualization, data analysis and interpretation, drafting of the article, and final approval. B. L. Horta collaborated in the data analysis and interpretation and revision of the article. J. J. F. Amaral adjusted the research instrument to the project's design and revised the article. P. F. C. B. C. Fernandes adjusted the research project and revised the draft. C. M. Galvão conducted a critical review of the article's content.

\section{References}

1. Parkin DM, Bray FI, Devesa SS. Cancer burden in the year 2000. The global picture. Eur J Cancer 2001; 37 Suppl 8: S4-66.

2. Instituto Nacional de Câncer. Estimativa da incidência e mortalidade por câncer no Brasil, 2007. http://www.inca.gov.br/cancer/epidemiologia/ estimativa2008 (accessed on 10/Jan/2008).

3. Instituto Nacional de Câncer. Controle do câncer de mama 2006. http://www.inca.gov.br/can cer/conteudo_view.asp?id=336 (accessed on 18/ Feb/2008).
4. Meister K, Morgan J. Risk factors for breast cancer. New York: American Council on Science and Health; 2000.

5. Instituto Nacional de Câncer. Controle do câncer de mama: documento de consenso; 2004. http:// www.inca.gov.br/publicacoes/consenso (accessed on 05/Apr/2007).

6. Sociedade Brasileira de Mastologia. Recomendações de Consenso. Carcinoma de mama: fatores de risco, 2001. http://www.portalmedico.org.br/ include/diretrizes/10 (accessed on 10/Jan/2007). 
7. Jonhnson-Thompson MC, Guthrie J. Ongoing research to identify environmental risk factors in breast carcinoma. Cancer 2000; $88(5$ Suppl):1224-9.

8. Helgesson O, Cabrera C, Lapidus L, Bengtsson C, Lissner L. Self-reported stress levels predict subsequent breast cancer in a cohort of Swedish women. Eur J Cancer Prevent 2003; 12:377-81.

9. Lillberg K, Verkasalo PK, Kaprio J, Teppo L, Helenius H, Koskenvuo M. Stressful life events and risk of breast cancer in 10,808 women: a cohort study. Am J Epidemiol 2003; 157:415-23.

10. Priestman TJ, Priestman SG, Bradshaw C. Stress and breast cancer. Br J Cancer 1985; 51:493-8.

11. Cooper CL, Cooper R, Faragher EB. Incidence and perception of psychosocial stress: the relationship with breast cancer. Psychol Med 1989; 19:415-22.

12. Forsén A. Psychosocial stress as a risk for breast cancer. Psychother Psychosom 1991; 55:176-85.

13. Geyer S. Life events, chronic difficulties and vulnerability factors preceding breast cancer. Soc Sci Med 1993; 37:1545-55.

14. Chen CC, David AS, Nunnerley H, Michell M, Dawson JL, Berry H, et al. Adverse life events and breast cancer: case-control study. BMJ 1995; 311:1527-30.

15. Ginsberg A, Price D, Ingram D, Nottage E. Life events and the risk of breast cancer: a case-control study. Eur J Cancer 1996; 32A:2049-52.

16. Protheroe D, Turvey K, Horgan K, Benson E, Bowers D, House A. Stressful life events and difficulties and onset of breast cancer: case-control study. BMJ 1999; 319:1027-30.

17. Roberts FD, Newcomb PA, Trentham-Dietz A, Storer BE. Self-reported stress and risk of breast cancer. Cancer 1996; 77:1089-93.

18. Petticrew M, Fraser J, Regan MF. Adverse lifeevents and risk of breast cancer: a meta-analysis. Br J Health Psychol 1999; 4:1-17.

19. Duijts SFA, Zeegers MP, Borne BV. The association between stressful life events and breast cancer risk: a meta-analysis. Int J Cancer 2003; 107:1023-9.

20. Ollonen P, Lehtonen J, Eskeline N. Stressful and adverse life experiences in patients with breast symptoms: a prospective case-control study in Kuopio, Finland. Anticancer Res 2005; 25:531-6.

21. Kornblith AB, Herndon JE, Zuckerman E, Viscoli CM, Horwitz RI, Cooper MR, et al. Social support as a buffer to the psychological impact of stressful life events in women with breast cancer. Cancer 2001; 91:443-54.

22. Palesh OG, Shaffer T, Larson J, Edsall S, Chen XH, Cheryl K, et al. Emotional self-efficacy, stressful life events, and satisfaction with social support in relation to mood disturbance among women living with breast cancer in rural communities. Breast J 2006; 12:123-9.

23. Graham J, RamirezA, Love S, Richards M, Burgess C. Stressful life experiences and risk of relapse of breast cancer: observational cohort study. BMJ 2002; 324:1420.

24. Cochrane Collaboration. Cochrane handbook for systematic reviews of interventions 4.2.6. http:// www.cochrane.org/resources/handbook/handbook.pdf (accessed on 15/Mar/2006).
25. Downs SH, Black N. The feasibility of creating a checklist for the assessment of the methodological quality both of randomized and non-randomized studies of health care interventions. J Epidemiol Community Health 1998; 52:377-84.

26. Kvikstad A, Vatten LJ, Tretli S, Kvinnsland S. Death of a husband or marital divorce related to risk of breast cancer in middle-aged women. A nested case-control study among Norwegian women born 1935-1954. Eur J Cancer 1994; 30A:473-7.

27. Ewertz M. Bereavement and breast cancer. Br J Cancer 1986; 53:701-3.

28. Melnyk BM, Fineout-Overholt E. Making the case for evidence-based practice. In: Melnyk BM, Fineout-Overholt E, editors. Evidence-based practice in nursing \& healthcare: a guide to best practice. Philadelphia: Lippincot Williams \& Wilkins; 2005. p. 3-24.

29. Burgess CC, Cornelius V, Love S, Graham J, Richards M, Ramirez A. Depression and anxiety in women with early breast cancer: five year observational cohort study. BMJ 2005; 330:702.

30. Dalton SO, Boesen EH, Ross L, Schapiro IR, Johansen C. Mind and cancer: do psychological factors cause cancer? Eur J Cancer 2002; 38:1313-23.

31. Gerits P. Life events, coping and breast cancer: state of the art. Biomed Pharmacother 2000; 54:229-33.

32. Kim Y, Duhamel KN, Valdimarsdottir HB, Bovbjerg DH. Psychological distress among healthy women with family histories of breast cancer: effects of recent life events. Psychooncology 2005; 14:555-63.

33. Lillberg K, Verkasalo PK, Kaprio J, Teppo L, Helenius $\mathrm{H}$, Koskenvuo M. A prospective study of life satisfaction, neuroticism and breast cancer risk (Finland). Cancer Causes Control 2002; 13:191-8.

34. Montazeri A, Jarvandi S, Ebrahimi M, Haghighat S, Ansari M. The role of depression in the development of breast cancer: analysis of registry data from a single institute. Asian Pac J Cancer Prev 2004; 5:316-9.

35. Papatestas AE, Mulvihill MN, Lesnick G, Aufses AH. Association of risk and prognostic in breast cancer. Prog Clin Biol Res 1997; 12:37-45.

36. Terra JL, Amiel-Lebigre F, Boujema F, Guyotat J, Guillaud-Bataille JM, Jurus M, et al. Evènements de la vie et cancer du sein: premiers resultants d'une etude comparative portent sur 100 cas et leurs témoins. Acta Psychiatr Belg 1986; 86:496-501.

37. Wakai K, Kojima M, Nishio K, Suzuki S, Niwa Y, Lin Y, et al. Psychological attitudes and risk of breast cancer in Japan: a prospective study. Cancer Causes Control 2007; 18:259-67.

38. Cheng Y, Kawachi I, Coakley EH, Schwartz J, Colditz G. Association between psychosocial work characteristics and health functioning in American women: prospective study. BMJ 2000; 320:1432-6.

39. De Brabander B, Gerits P. Chronic and acute stress as predictors of relapse in primary breast cancer patients. Patient Educ Couns 1999; 37:265-72.

40. Jacobs JR, Bovasso GB. Early and chronic stress and their relation to breast cancer. Psychol Med 2000; 30:669-78.

41. Kruk J, Aboul-Enein HY. Psychological stress and the risk of breast cancer: a case-control study. Cancer Detect Prev 2004; 28:399-408. 
42. Manuel JC, Burwell SR, Crawford SL, Lawrence RH, Farner DF, Hege A, et al. Younger women's perceptions of coping with breast cancer. Cancer Nurs 2007; 30:85-94.

43. Tomich PL, Helgeson VS, Nowak Vache EJ. Perceived growth and decline following breast cancer: a comparison to age-matched controls 5-years later. Psychooncology 2005; 14:1018-29.

44. Metcalfe C, Smith GD, Macleod J, Hart C. The role of self-reported stress in the development of breast cancer and prostate cancer: a prospective cohort study of employed males and females with 30 years of follow-up. Eur J Cancer 2007; 43:1060-5.

45. Burgess CC, Ramirez AJ, Smith P, Richards MA. Do adverse life events and mood disorders influence delayed presentation of breast cancer? J Psychosom Res 2000; 48:171-5.

46. Achat H, Kawachi I, Byrne C, Hankinson S, Colditz G. Prospective study of job strain and risk of breast cancer. Int J Epidemiol 2000; 29:622-8.

47. Schernhammer ES, Hankinson SE, Rosner B, Kroenke CH, Willett WC, Colditz GA, et al. Job stress and breast cancer. Am J Epidemiol 2004; 160:1079-86.

48. Lillberg K, Verkasalo PK, Kaprio J, Teppo L, Helenius H, Koskenvuo M. Stress of daily activities and risk of breast cancer: a prospective cohort study in Finland. Int J Cancer 2001; 91:888-93.

49. Sherliker L, Steptoe A. Coping with new treatments for cancer: a feasibility study of daily diary measures. Patient Educ Couns 2000; 40:11-9.

50. Mehnert A, Koch U. Prevalence of acute and posttraumatic stress disorder and comorbid mental disorders in breast cancer patients during primary cancer care: a prospective study. Psychooncology 2007; 16:181-8.

51. Petro-Nustas W. Health-related behaviors and lifestyle factors of patients with breast cancer. Cancer Nurs 2002; 25:219-29.

52. Koopman C, Angell K, Turner-Cobb JM, Kreshka MA, Donnelly P, McCoy R, et al. Distress, coping, and social support among rural women recently diagnosed with primary breast cancer. Breast J 2001; 7:25-33.

53. Price MA, Tennant CC, Butow PN, Smith RC, Kennedy SJ, Kossoff MB, et al. The role of psychosocial factors in the development of breast carcinoma: part II. Cancer 2001; 91:686-97.

54. Bleiker EMA, Pouwer F, van der Ploeg HM, Leer JWH, Adèr HJ. Psychological distress two years after diagnosis of breast cancer frequency and prediction. Patient Educ Couns 2000; 40:209-17.

55. Cox T, Mackay C. Psychosocial factors and psychophysiological mechanisms in the aetiology and development of cancers. Soc Sci Med 1982; 16: 381-96.

56. Edwards JR, Cooper CL, Pearl SG, Paredes ES, O'Leary T, Wilhelm MC. The relationship between psychosocial factors and breast cancer: some unexpected results. Behav Med 1990; 16:5-14.

57. Geyer S. The role of social and psychosocial factors in the development and course of cancer. Wien Klin Wochenschr 2000; 112:986-94.

58. Giraldi T, Rodani MG, Cartei G, Grassi L. Psychosocial factors and breast cancer: a 6-year Italian follow-up study. Psychother Psychosom 1997; 66:229-36
59. Low CA, Stanton AL, Thompson N, Kwan L, Ganz PA. Contextual life stress and coping strategies as predictors of adjustment to breast cancer survivorship. Ann Behav Med 2006; 32:235-44.

60. Hilakivi-Clarke L, Rowland J, Clarke R, Lippman ME. Psychosocial factors in the development and progression of breast cancer. Breast Cancer Res Treat 1993; 29:141-60.

61. Nielsen NR, Zhang ZF, Kristensen TS, Netterstrom B, Schnohr P, Gronbaek M. Self reported stress and risk of breast cancer: prospective cohort study. BMJ 2005; 331:548.

62. Barraclough J, Osmond C, Taylor I, Perry M, Collins P. Life events and breast cancer prognosis. BMJ 1993; 307:325.

63. Barraclough J. Adverse life events and breast cancer. Other studies have found no association. BMJ 1996; 312:845.

64. Burke MA, Goodkin K. Stress and the development of breast cancer: a persistent and popular link despite contrary evidence. Cancer 1997; 79:1055-9.

65. Israël L. Stress and relapse of breast cancer. BMJ 1989; 298:1032.

66. McGee R. Does stress cause cancer? There's no good evidence of a relation between stressful events and cancer. BMJ 1999; 319:1015-6.

67. Wood J, Gilmore OJ, Popert RJ. Stress and relapse of breast cancer. BMJ 1989; 298:962-3.

68. Bryla CM. The relationship between stress and the development of breast cancer: a literature review. Oncol Nurs Forum 1996; 23:441-8.

69. Love RR, Love SM, Laudico AV. Breast cancer from a public health perspective. Breast J 2004; 10: 136-40.

70. De Boer MF, Ryckman RM, Pruyn JFA, Van den Borne HW. Psychological correlates of cancer relapse and survival: a literature review. Patient Educ Couns 1999; 37:215-30.

71. Butow PN, Hiller JE, Price MA, Thackway SV, Kricker A, Tennant CC. Epidemiological evidence for a relationship between life events, coping style, and personality factors in the development of breast cancer. J Psychosom Res 2000; 49:169-81.

72. Nielsen NR, Grønbaek M. Stress and breast cancer: a systematic update on the current knowledge. Nat Clin Pract Oncol 2006; 3:612-20.

73. Aro AR, De Koning HJ, Schreck M, Henriksson M, Anttila A, Pukkala E. Psychological risk factors of incidence of breast cancer: a prospective cohort study in Finland. Psychol Med 2005; 35:1515-21.

74. Cooper CL, Faragher EB. Psychosocial stress and breast cancer: the inter-relationship between stress events, coping strategies and personality. Psychol Med 1993; 23:653-62.

75. Faragher EB, Cooper CL. Type A stress prone behaviour and breast cancer. Psychol Med 1990; 20:663-70.

76. Liste KH. Breast cancer, personality and the feminine role. Patient Educ Couns 1999; 36: 33-45.

77. McKenna MC, Zevon MA, Corn B, Rounds J. Psychosocial factors and the development of breast cancer: a meta-analysis. Health Psychol 1999; 18:520-31. 
78. Buscemi N, Vandermeer B, Hooton N, Pandya R, Tjosvold L, Hartling L, et al. Efficacy and safety of exogenous melatonin for secondary sleep disorders and sleep disorders accompanying sleep restriction: meta-analysis. BMJ 2006; 332:385-93.

79. Nomura K, Nakao M, Morimoto T. Effect of smok ing on hearing loss: quality assessment and metaanalysis. Prev Med 2005; 40:138-44.

80. Sclowitz IKT, Santos IS. Fatores de risco na recorrência do baixo peso ao nascer, restrição de crescimento intra-uterino e nascimento pré-termo em sucessivas gestações: um estudo de revisão. Cad Saúde Pública 2006; 22:1129-36.

81. Albernaz E, Victora CG. Impacto do aconselhamento face a face sobre a duração do aleitamento exclusivo: um estudo de revisão. Rev Panam Salud Pública 2003; 14:17-24.

82. Brouwers MC, Johnston ME, Charette ML, Hanna SE, Jadad AR, Browman GP. Evaluating the role of quality assessment of primary studies in systematic reviews of cancer practice guidelines. BMC Med Res Methodol 2005; 5:8.
83. Jalowiec A. Jalowiec Coping Scale. Chicago: University of Illinois; 1987.

84. Lazarus R, Folkman S. Stress, appraisal and coping. New York: Springer; 1984.

85. Souza JN, Chaves EC, Caramelli P. Coping in aged people with Alzheimer's disease. Rev Latinoam Enferm 2007; 15:93-9.

86. Sackett DL, Straus SE, RichardsonWS, RosenbergW, Haynes RB. Medicina baseada em evidências: prática e ensino. Porto Alegre: Editora Artmed; 2003.

87. Fletcher RH, Fletcher SW, Wagner EH. Epidemiologia clínica: elementos essenciais. Porto Alegre: Editora Artmed; 1996.

Submitted on 14/May/2009

Final version resubmitted on 15/Sep/2009

Approved on 23/Sep/2009 